\title{
Increasing tourism competitiveness: Connecting Blue and Green Croatia
}

\author{
Ivan Kelić \\ Faculty of Economics in Osijek, J. J. Strossmayer University of Osijek, Croatia \\ Aleksandar Erceg \\ Faculty of Economics in Osijek, J. J. Strossmayer University of Osijek, Croatia \\ Ivana Čandrlić-Dankoš \\ Department of Investment, Development Projects and European Union Funds in Osijek-Baranja County, \\ Croatia
}

Received: 3 February 2020. Revision received: 27 May 2020. Accepted: 2 June 2020

\begin{abstract}
The objective of this article is to identify if unique local food and local cuisine in some regions can be used as a marketing tool to attract visitors to a destination and increase its competitiveness. This article focuses on establishing success criteria for cooperation between companies from so-called blue (Coastal) and so-called green (Continental Eastern) Croatia for increasing competitiveness of tourism destination. To gain insight into the most important trends in connecting blue and green Croatia, primary research was conducted on identification preferences referring to how high-quality products carry a strong tourist identity of green Croatia. For the purpose of a survey, the authors used a sample of 134 industry experts involved in developing tourism products through formal or informal activities. The first level of research was to explore consumer interrelation based on the frequency of using domestic and foreign products. In the second part, respondents were invited to express a degree of agreement with certain statements. The results indicated that there is statistical significance between the female sex and information on the origin of products, raw materials, and foodstuffs and recipes (education) for the preparation of a product. The paper makes a recommendation on how small and medium-size producers can increase their competitiveness and have better sales results and at the same time give policy recommendations to local and regional governments. As recommendations for further research, we propose to examine a) the economic impact at the national level; and b) the economic impact of programs aimed at connecting blue and green Croatia on both included parts.
\end{abstract}

Key Words: competitiveness; blue Croatia; green Croatia; recommendations.

JEL Classification: L82, Z32

Reference: Kelić, I., Erceg, A. \& Čandrlić Dankoš, I. (2020). Increasing tourism competitiveness: Connecting Blue and Green Croatia. Journal of Tourism and Services, 20(11), 132-149. doi: 10.29036/jots.v11i20.138

\section{Introduction}

According to the "Tourism Development Strategy of the Republic of Croatia until 2020", the European Union recognises Croatia as a tourist destination with growth potential. Using the value system of sustainable development, this status opens significant opportunities for both tourism and economic development. Croatia attracts visitors for its natural environment, historical heritage and cultural richness rather than availability, quality and diversity of tourist attractions.

However, the academic literature suggests that Croatia is not alone in those perspectives. In the past, tourism prioritised the sense of sight, i.e., landscapes, buildings, art and museums, while today 


\section{JOURNAL OF TOURISM AND SERVICES}

Issue 20, volume 11, ISSN 1804-5650 (Online)

www.jots.cz

tourists demand trips encouraging other senses to enjoy (Lopez-Guzman et al., 2018). Previous tourism activities included activities considering the sea, beaches, and the sun. Later on, alternative tourism activities (related to health, culture, sports, and religion) started to gain importance as new tourism products. Similarly, with the aim of strengthening tourism through the extension of the tourist season, the Croatian Strategy has identified products with growth potential. One of those products is gastronomy.

Slavonija, Baranja and Western Syrmia have been known as an agricultural region (so-called green Croatia), which offers great potential for the development of gastronomy. The question is if gastronomy could empower underdeveloped connections between blue (coastal) and green (continental) Croatia? Connections led in two directions based on the "win-win" concept for both. One direction is based on the production in Slavonija, Baranja and Western Syrmia and the distribution through the chains in the blue part, whereas the other direction could include trips from blue to green Croatia based on a combination of gastronomic, rural and other sorts of selective tourism.

Thus, the main objective of the paper is to examine if local food and cuisine from so-called green Croatia can be used as a marketing tool to attract visitors to blue Croatia and to increase its competitiveness. For our research, we used SPSS software for statistical data processing and the following methods: descriptive statistics, analysis of variance (ANOVA), and correlation analysis.

The rest of the paper is organised as follows. The second section gives a literature review of competitiveness in tourism, gastronomy and gastronomic tourism. Section 3 analyses tourism-related data in the Republic of Croatia. In the fourth section, we present research results in relation to identification preferences referring to how high-quality products carry a strong tourist identity of green Croatia. Based on the research results, we present conclusions and suggestions for further research.

\section{Literature review}

Tourism represents one of the biggest sectors in economy and is seen as significant characteristic for the development. It contributes to the national economy due to its multiplier effects on creating business opportunities and employment development (Sharma, 2004; Gozgor \& Demir, 2018).

Competitiveness in tourism has been a topic of many research studies (Vanhove, 2002; Ritchie \& Crouch, 2003; Dimanche 2005; Mangion, Durbarry \& Sinclair, 2005; Enright \& Newton, 2005, Navickas \& Malakauskaite, 2009; Crouch, 2010; Kozicka, et al., 2019). They have studied different aspects of tourism competitiveness and this research is important not only for the scientific but also for the practical point of view. The scientists in the papers (Dkhili, 2018; Kendiukhov et al., 2017) proved that tourism should develop considering the sustainable development goals. Due to the competitive tension, new solutions and variety of alternatives occur (Peleckis et al., 2018). Destination competitiveness is created from its resources and it can be classified into inherited (historical, cultural, natural), human-created and supporting sources (e.g. basic infrastructure, quality of service, (Dwyer \& Kim, 2003). Ritchie and Crouch (2003) presented one of the best models for destination competitiveness. Their model uses accepted characteristics that influence destination competitiveness while taking into consideration macroenvironmental and micro-environmental forces (Crouch, 2010). The model combines five groups (core resources and attractors, destination management, acceleration resources, supporting resources and destination management, planning and destination policy management). Similar model of destination competitiveness was presented by Dwyer and Kim (2003).

One of the core resources and attractors for the destination is gastronomy. Angelkova et al. (2012) state that tourism competitiveness starts with the experience which tourist acquires at the destination. They additionally conclude that competitiveness in tourism can be seen as ability to increase tourist consumption and to attract more tourists while supplying them with satisfying experience. One of that experiences is food tourist eats - the gastronomy of the tourist destination. Potentials of gastronomy and gastronomic tourism are constantly being presented in the academic literature (Berbel-Pineda et al., 2019; 


\section{JOURNAL OF TOURISM AND SERVICES}

Issue 20, volume 11, ISSN 1804-5650 (Online)

www.jots.cz

Elis et al., 2018; Ignatov \& Smith, 2006). Cagh (2012) examined the financial impact of tourism as one of the most important eco-nomic sectors with the great multiplier effect economically, which makes it an ideal means of development. Analysis of a steady increase in tourism and its contribution to GDP is a challenging task for tourism planners and marketers in terms of new product development and optimal use of available tourism assets as a key to sustainable economic development (Seal, 2018; Haseeb et al., 2019). It should be maintained as an economic sector which supports regional development and strengthens local identity. Therefore research, studies, and projects on gastronomy should be carried out nationwide and at international level, through further broadcasts, panels, workshops, training, and attention, leading to the introduction and promotion of gastronomy tourism that should be arranged (du Rand \& Heath, 2006; Okumus et al., 2007; Kim et al., 2009; Yozukmaz et al., 2017, Pineda et al., 2019).

Recently gastronomy and gastronomic tourism have become a basic part of tourism destination attractiveness since gastronomy tourism has become a significant part of the tourism industry (Horng \& Tsai, 2010). Chi et al. (2013) investigated structural relationships between food image, food satisfaction, culinary quality and behavioural intentions in Malaysia. They found out that different cultures have a different point of view regarding Malaysian food and food in general. However, they concluded that food contributes to destination tourism. Hjalager (2004) divided gastronomy tourists into the following four types: (i) recreational, (ii) existential, (iii) diversionary, and (iv) experimental. Sormaz et al. (2016) suggest that a tourist wishes to experience local tastes as an unavoidable part of the tourist offer. Dishes unique to the region or an area may be an element of awareness for the region or an area. Along with the phenomenon of eating to live, a new phenome-non, i.e., living to eat, has emerged recently due to changes in eating habits and eating out that has become common (Deveci et al., 2013). Kivela and Crotts (2008) identified that gastronomy is inseparably connected to a destination's image and the destination itself. By exploring gastronomic perception and motivation of a tourist destination in Quito, López-Guzmán et al. (2018) suggest that practical implications centred on a better understanding of the key factor that could reinforce a tourist destination and achieve traveller satisfaction. Positive impacts of gastronomy are considered crucial in deciding on revisiting and recommending a tourist destination (Chi et al., 2013; Kumar, 2019). Cooperation between different stakeholders in process of developing destination contributes to the creation and promotion of its innovative processes through the stakeholders' knowledge exchange (Pjerotic, 2017).

Some authors point out that connections between gastronomy and tourism have changed and are still changing over time. First, gastronomy was a tourist product. With further development, gastronomy and tourism coexisted in synergy (gastronomy is a component of a destination, etc.). Current trends show that gastronomy and tourism are based on two different assumptions: gastronomy as a tourist attraction and new experience related to increased interest in gastronomy as an important part of a tourist trip (López-Guzmán et al., 2018). Moreover, some regions can be recognized or symbolized since gastronomy is a crucial part of culture, e.g., the Czech Republic is known as the country famous for its beer, Italy for its pizza and pasta, and France and Chile for their Champagne and Burgundy (Sormaz et al., 2016).

By exploring the impact of typical products on the decision to (re)visit a tourist destination Alderight et al. (2016) surveyed tourist intentions to visit or revisit three popular mountain destinations in Northern Italy. The survey based on respondents' experiences, knowledge and appreciation of wellknown products has confirmed a strong positive effect of typical products (including gastronomy) on a decision to (re)visit a destination. Furthermore, the authors noted that tasting dishes is one of the five reasons why foreign tourists prefer some destinations over others (Sormaz et al., 2016).

On the other hand, some researchers claim tourism and gastronomy represent two different behavioural segments. The first group consists of tourists for whom gastronomy is the main reason for their visit, while for the second group, a destination is priority and gastronomy are something that comes along. Diversity of groups lies in recommendations, intention to return and the perception of a destination and the quality of service provided by restaurants. The authors suggested that travel planners should be oriented towards the second group and try to reach their satisfaction to transfer them to the 


\section{JOURNAL OF TOURISM AND SERVICES}

Issue 20, volume 11, ISSN 1804-5650 (Online)

www.jots.cz

first group. If they succeeded, they could expect their return and an increasing number of new clients based on recommendations (Daries et al., 2018).

Though gastronomy itself is a form of selective tourism, there are authors interested in a specific part of gastronomy. Special attention in the academic literature is given to so-called wine tourism. To provide a better understanding of a wine tourist, various wine tourist typologies have been created. The main criteria were socio-economic and psychographic data. The authors concluded that there is a significant difference in tourists based on demographic data, age, education, and gender. In terms of demographic data, differences between the old and the new world were investigated. On the other hand, tourists from the old continent are mainly consumers with seeking for 4S: sun, sex sea and sand. Several additional market segments have been identified, which leads to the conclusion that some additional research should be conducted to support the segmentation mentioned previously (Alebaki, 2011). The complexity of gastronomy as an art is shown in Figure 1.

Figure 1. A multidisciplinary model for the science of gastronomy

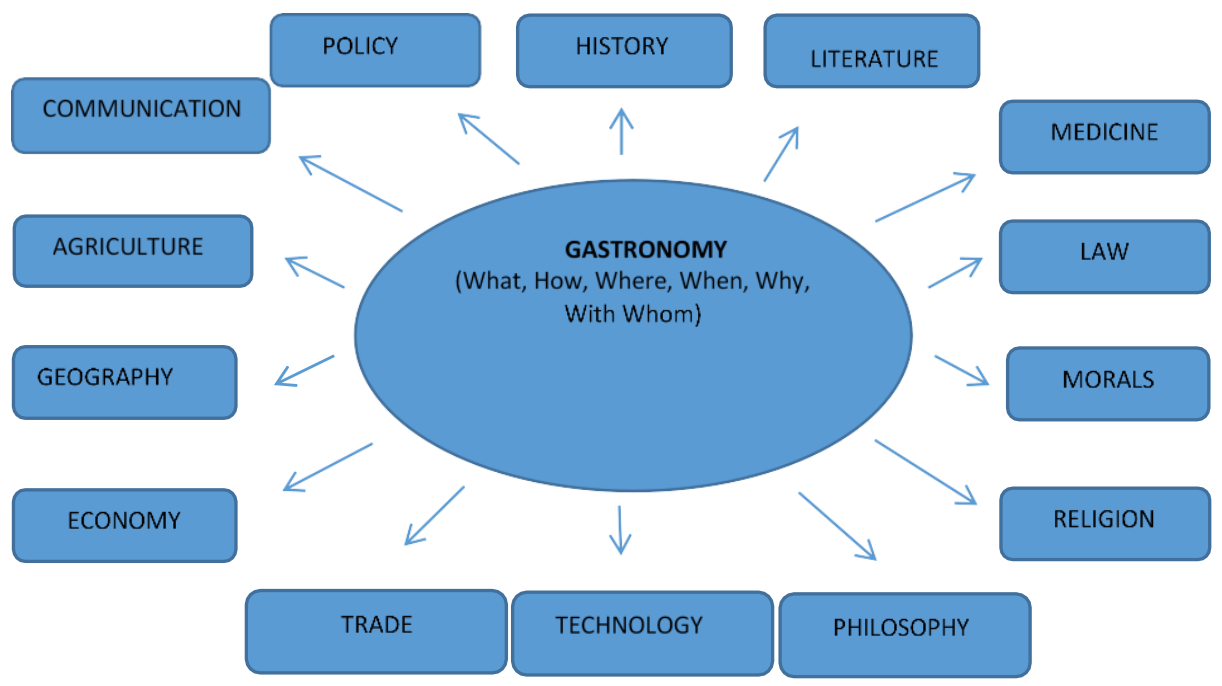

Source: Adapted from Zahari et al., 2009

In general, the overall conclusion referring to gastronomy and tourism is that as a selective type of tourism, gastronomy is an economic branch with potential and worth investing in. However, in the example of wine tourism, it could suggest that a multidisciplinary approach should be considered.

López-Guzmán et al. (2018) suggest that each region could promote its own cuisine to attract tourists. The authors state that in the city of Quito gastronomy can become a key factor in the competitiveness of tourist destinations, and thus the focus on gastronomy becomes a basic tool for the promotion of a geographical area. This is also the case with several more academic papers (Berbel-Pineda et al., 2019; Kumar, 2019; Galvez et al., 2017; Lopez-Guzman \& Sanchez-Canizares, 2012; Henderson, 2004).

Research on the possibilities of authentic food in Hungarian households of Vojvodina and its contribution to the development of gastronomic tourism has proven a significant impact and future potential of traditional meals as a tool for economic development in a rural area in Vojvodina (Kalenjuk, 2018).

It is observed that many precautions are taken to protect the richness of regional cuisines utilizing unique geographical, cultural, and climatic factors (Sormaz et al., 2016). The authors state that one of the best examples for this is control on the Barrosã beef in Portugal, where these animals must be fed only with local feeds and grasses and must not be given any feed other than that of organic and local origin 


\section{JOURNAL OF TOURISM AND SERVICES}

Issue 20, volume 11, ISSN 1804-5650 (Online)

www.jots.cz

during their growth, which prevents the production of the same products in any other places, thus providing a competitive advantage.

\section{Materials and Methods}

To gain insight into the most important trends in connecting so-called blue and so-called green Croatia, primary research was conducted on identification preferences referring to how high-quality products carry a strong tourist identity of green Croatia. The paper aims to fill the gap existing in research about competitiveness of Croatian tourism concerning gastronomy and connection of two different parts of the Republic of Croatia. The gastronomy and its influence on tourism competitiveness in Croatia is not adequately research. There are only several studies about this topic in Croatia including Drpić and Vukman (2014) who investigated gastronomy as an important part of Croatian tourism offer, Pranić (2012) who studied features of Adriatic Croatia gastronomy offer and Sudarić Zmaić and Čepo (2020) who studied development of eno-gastronomy tourist destination. But there was no similar research about this topic in Croatia and thus it was not possible to compare research results, and this presents the research limitation. There are several professional articles and initiatives in Croatia which were taken into consideration and explained in results and discussion part of the paper.

During research for this paper we have set following steps of research methodology: step 1 secondary data gathering; step 2 - establishing the group of experts; step 3 - creating the questionnaire; step 4 - conducting survey; step 5 - analysing the data; step 6 - creating research findings and conclusion.

In the survey, we used a sample of experts involved in developing tourism products through formal or informal activities. The sample of industry experts consisted of individuals whose work experience is related to tourism management and have formal (high school or university degree) or nonformal (expert seminars, lifelong programs) education in the field of tourism. For research purposes a appropriate sample of industry experts included tourist managers, tourist guides, Marketing and Entrepreneurship professors and public sector employees managing tourist products (Mérszáros \& Divékyová, 2019). An online survey was conducted in green Croatia in the period from August to September 2018. The online questionnaire was sent to 565 e-mail addresses (e-mail database of Alumni of faculty of Economics), and 134 respondents answered the questionnaire. In research, industry experts were asked to rank the importance and performance of different attributes. The questionnaire, divided into two sections, consisted of 25 closed questions, 19 of which were designed by using a 5-point Likert scale. The questionnaire was created and adapted according to the model of Consumer Ethnocentric Tendency Scale - CETSCALE (Shimp and Sharma, 1987). The questionnaire was adjusted according to the statements measuring consumer ethnocentrism and attitudes. The degree of agreement with each of these statements was expressed by participants using a five-point Likert scale. The first section includes psychographic and demographic questions. The second part relates to the attributes industry experts rated through statements on certain aspects referring to the competitiveness of gastronomic products of green Croatia and the importance of individual factors with the aim of successful placement of gastronomic products of green Croatia on the market of blue Croatia. Survey results were analysed using SPSS software for statistical data processing. For research data analyses, we used descriptive statistics, analysis of variance (ANOVA), and correlation analysis.

\section{Results and discussion}

Slavonija, Baranja and Western Syrmia have great potential in gastro-tourism; the question arises as to how to strengthen the potentials relating green and blue Croatia. Some previously identified directions should be further explored. 


\section{JOURNAL OF TOURISM AND SERVICES}

Issue 20, volume 11, ISSN 1804-5650 (Online)

www.jots.cz

By determining the target groups as well as value-added products that carry a strong identification with a certain geographical area it is possible to create the preconditions for branding the agricultural and food products of the region of Slavonia, Baranja and Syrmia. Consequently, it is possible to increase their degree of recognizability that enables their better market placement.

Although there are no relevant studies at the scientific level on the effects of linking green and blue Croatia, the Croatian tourism development strategy has defined products with a clear development perspective, of which particular emphasis is placed on gastronomy and enology. Although gastronomy and enology as a tourist product were most developed in Istria and then in Dalmatia and Slavonia, a systematic approach to the development of gastronomic and oenological tourism offer is still undervalued. However, it is already for many years, an integral part of the country's tourism promotion (Tourism Development Strategy of the Republic of Croatia until 2020, 2013, 9).

Stronger connections between continental and coastal Croatia is one of the oldest economic concepts in Croatia. It has changed through the history, but the development of tourism as an economic branch has opened new possibilities. The economic value of this concept lies in great agricultural production in continental Croatia sold to its coastal counterpart through tourism. Though agricultural production is only one of economic branches, it is typical of continental Croatia and can expand to total production. On the one hand, high-quality products encourage tourism, and on the other, they have a great market potential. There are several statistical reports supporting this concept, e.g., tourism revenues in Croatia and the EU have not only significantly increased, but there are trends that suggest further increases, then since 2014, one of ten small enterprises in the EU has been registered in the tourist industry, etc.

Controversially, although these facts are known, the concept itself continuously collapses. There were some intentions to connect, and there were some movements, but the impact and results are below expectation. The Croatian Chamber of Trades and Crafts organizes a manifestation in Požega under the name "green-blue", where trades and crafts from coastal and continental Croatia meet, which has resulted in business operations, but for better results, further steps should be taken.

The research results in this paper are divided into the secondary data research results which should present importance of the tourism for the Croatian national economy and into the primary research which is conducted with questionnaire. In the final part of the research, we are presenting an example of good practice in connecting Blue and Green Croatia.

\subsection{Tourism in Croatia}

Statistical data could provide a better insight into potentials. Since 1954, statistical reports have suggested a significant increase in tourism as a branch. Out of 1,000 tourist arrivals recorded in 1954, the number has grown to 17,431,000 arrivals in 2017 (Figure 2).

In the same period, the number of tourist overnight stays has increased from 3,682 in 1954 to 86,200 in 2017 (Figure 3). Further analysis has shown an increase in trends of 10\%. This trend has been present in the last five years and according to some speculations, it will rise in years to come. Although speculations are optimistic, producers find that the current situation already reveals significant market potential, with or without speculation.

Further analyses of counties confirm higher potential of coastal Croatia as a product market since $90 \%$ of total tourist arrivals and overnight stays were recorded there (Figure 4). 
Figure 2. Tourist arrivals in Croatia (in '000)

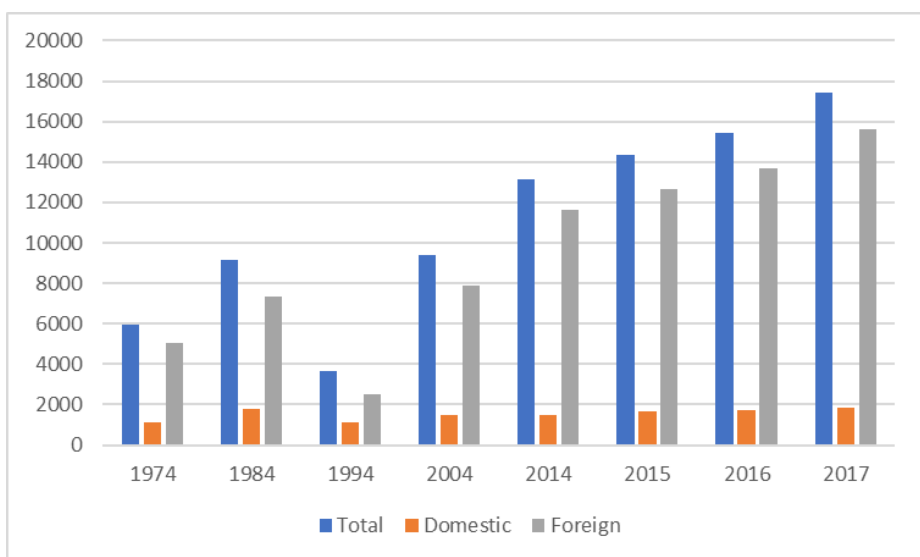

Sources: Authors, based on the National Bureau of Statistics data

Figure 3. Tourist overnight stays in Croatia (in '000)

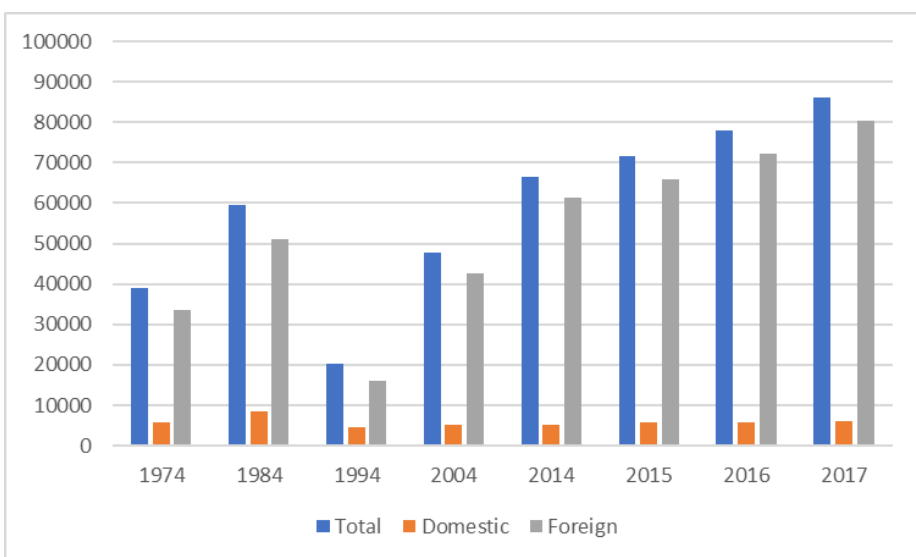

Sources: Authors, based on the National Bureau of Statistics data

Figure 4. Comparison of coastal and continental Croatia in '000

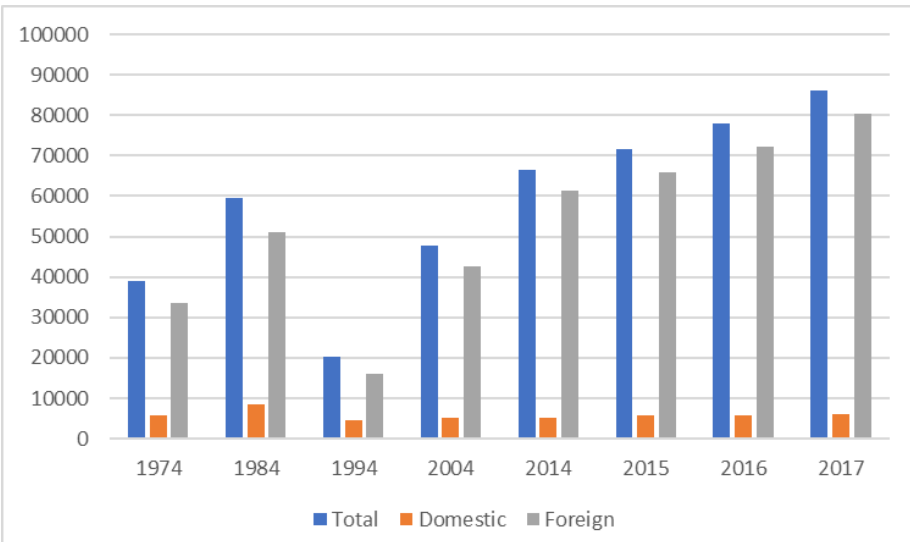

Sources: Authors, based on the National Bureau of Statistics data 


\section{JOURNAL OF TOURISM AND SERVICES}

Issue 20, volume 11, ISSN 1804-5650 (Online)

www.jots.cz

Previous figures present increase of arrivals and tourist overnight stays in Croatia in last 40 years making tourism in Croatia significantly important for the national economy. The numbers of tourists coming to Croatia are growing but in order to create and maintain competitive advantage with other tourist countries it is necessary to utilize better resources Croatia has. The gastronomy is one of those factors needed for destination competitiveness (Ritchie \& Crouch, 2003) since it represents one of the core attractors (Angelkova et al., 2012) for tourist to come to, in this case, Croatia. The success of strategy for destination competitiveness depends not only on external conditions but mainly on internal sources and the ways how to use them (Luštický \& Kincl, 2012: 101).Thus, in order to maintain the growth of the tourist numbers in Croatia it is needed to improve different processes within Croatia and one of those processes is connecting blue and green Croatia.

\subsection{Industry experts survey}

Primary research included 134 industry experts involved in developing tourism products through formal or informal activities. The sample structure is shown in Table 1.

Table 1. Sample structure

\begin{tabular}{|c|c|c|}
\hline $\mathrm{N}=134$ & Indicator & $\%$ \\
\hline \multirow{2}{*}{ Gender } & $\mathrm{M}$ & $43.40 \%$ \\
\hline & $\mathrm{F}$ & $56.60 \%$ \\
\hline \multirow{5}{*}{ Age } & $20-29$ & $22.00 \%$ \\
\hline & $30-39$ & $31.40 \%$ \\
\hline & $40-49$ & $31.40 \%$ \\
\hline & $50-59$ & $10.70 \%$ \\
\hline & 60 and older & $4.40 \%$ \\
\hline \multirow{5}{*}{ Level of education } & High school & $12.60 \%$ \\
\hline & Undergraduate study & $12.60 \%$ \\
\hline & Graduate study & $42.10 \%$ \\
\hline & Postgraduate study & $22.00 \%$ \\
\hline & Postgraduate doctoral study & $10.70 \%$ \\
\hline \multirow{3}{*}{$\begin{array}{c}\text { Status of a tourist } \\
\text { company / Working } \\
\text { status }\end{array}$} & Private sector & $39.10 \%$ \\
\hline & Public sector & $53.80 \%$ \\
\hline & Other* & $7.00 \%$ \\
\hline
\end{tabular}

The purpose of research is to clarify theoretically and practically the process of making purchasing decisions and explore their interrelation based on the frequency of use of domestic and foreign products. The concept of ethnocentrism has two essential components - attitude and behavior. Ethnocentric attitudes are evident in the creation of one's groups as dominant over other groups, and ethnocentric behavior represents cooperation with members of one's groups, with unstable cooperation with members of other groups (Veljković, 2009). As a measure of consumer ethnocentrism, four parts of the comprehensive questionnaire were used, from the category of purchasing attitudes. The task of the participant was to estimate the number of Likert type 1 to 5 as far as each claim is concerned, with 1 "completely disagree" and 5 "completely agree". Consumer ethnocentrism is counted as the average score on these four particles. Characteristics of the individual particle scale are shown in Table 2. 


\section{JOURNAL OF TOURISM AND SERVICES}

Issue 20, volume 11, ISSN 1804-5650 (Online)

www.jots.cz

Table 2. Metric characteristics of individual particles of consumer ethnocentrism scale

\begin{tabular}{|l|c|c|c|c|}
\hline \multicolumn{1}{|c|}{$\mathrm{N}=134$} & $\mathrm{M}$ & $\mathrm{Me}$ & Mo \\
\hline $\begin{array}{l}\text { Whenever I can always buy } \\
\text { domestic rather than foreign / } \\
\text { imported products. }\end{array}$ & 4.22 & 0.90 & 4.5 & 5 \\
\hline $\begin{array}{l}\text { I rather choose products of } \\
\text { Croatian origin than foreign / } \\
\text { imported products. }\end{array}$ & 4.20 & 0.90 & 4 & 5 \\
\hline $\begin{array}{l}\text { I have more confidence in } \\
\text { domestic rather than foreign / } \\
\text { imported products. }\end{array}$ & 4.03 & 1.00 & 4 & 5 \\
\hline $\begin{array}{l}\text { I'm trying to buy domestic } \\
\text { products to help the Croatian } \\
\text { economy. }\end{array}$ & 4.33 & 0.92 & 5 & 5 \\
\hline
\end{tabular}

Source: Authors

As can be seen from Table 2, all three central tendency measures are uniformed across all four particles. The middle position value shows that $50 \%$ of the answers were in the domain of response $1-4$, while $50 \%$ were in response domains 4 and 5 , meaning that half of the participants selected high levels of scale or represented moderately high to high levels of consumer ethnocentrism. The most common answer was the answer 5 that could suggest a high level of consumer ethnocentrism among the participants. This part of the research is a theoretical and practical analysis of consumer ethnocentrism of respondents and their relationship to variables and actual purchasing behavior. The fundamental aim was to deepen theoretically analyze the concept of consumer ethnocentrism, its determinants and components and link that construct to actual purchasing behavior, which is also the ultimate goal of marketing experts in consumer behavioral research.

Respondents assessed that green Croatia has its own gastronomic products recognized in the rest of Croatia, and $71.8 \%$ of them think that they are distinctly recognizable (Figure 5).

Figure 5. Green Croatia has its own gastronomic products that are recognized in the rest of Croatia

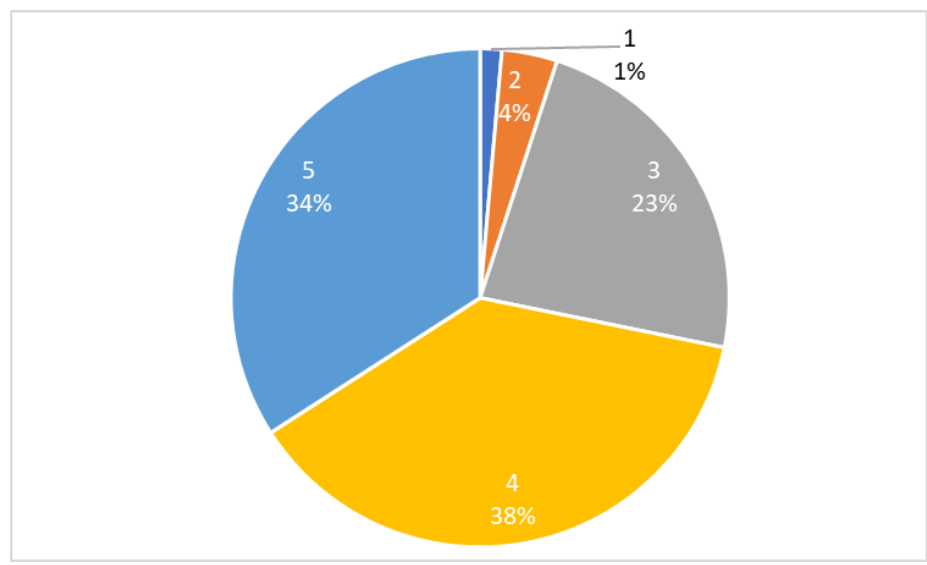

Legend: 1 "completely disagree" ... 5 "completely agree"

Source: Authors 


\section{JOURNAL OF TOURISM AND SERVICES}

Issue 20, volume 11, ISSN 1804-5650 (Online)

www.jots.cz

In the survey, respondents were asked to indicate to what extent Eastern Croatia has its own gastronomic products that are branded and protected. The results show that most respondents neither agree nor disagree with the claim that the products are not sufficiently recognizable and branded (36.3\%) (Figure 6).

Figure 6. Green Croatia has its own gastronomic products that are branded and protected

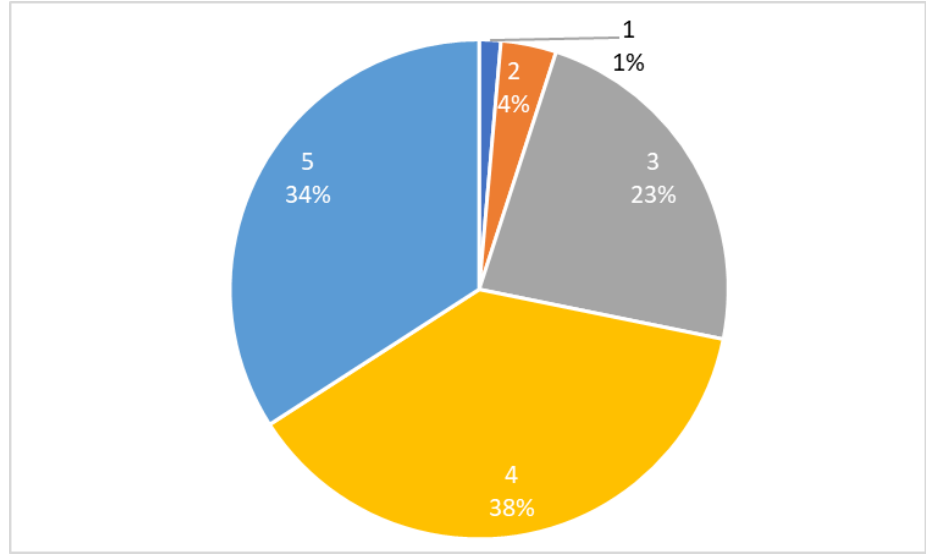

Legend: 1 "completely disagree"... 5 "completely agree"

Source: Authors

Since promotion was one of the elements of successful placement of products on the market, respondents were invited to assess whether green Croatia has highly developed promotional activities of its gastronomic products on the Croatian market. The results indicate that the largest number of respondents disagree with this statement (51.1\%) and consider that the products of green Croatia are not sufficiently promoted (Figure 7).

Figure 7. Green Croatia has highly developed promotional activities of its gastronomic products on the Croatian market

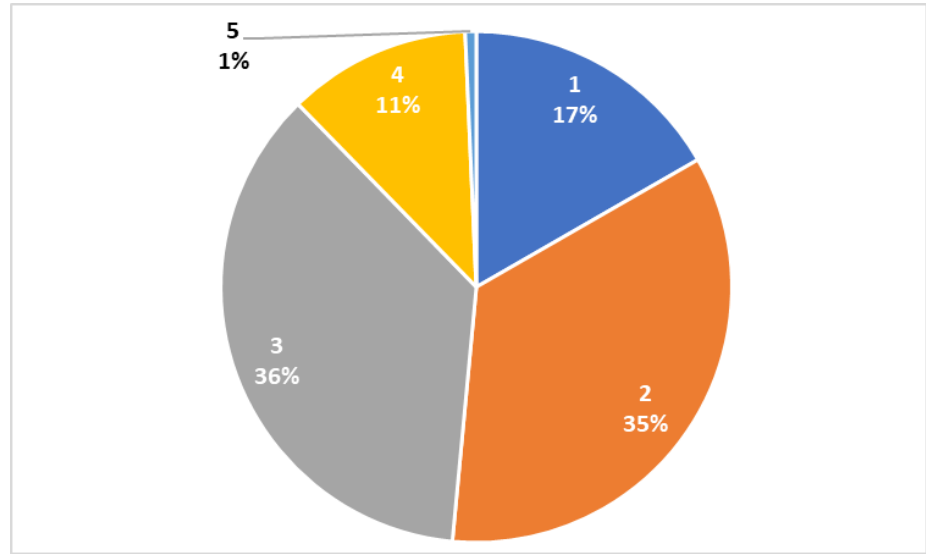

Legend: 1 "completely disagree"... 5 "completely agree"

Source: Authors

Most respondents disagree with the claim that so-called green Croatia successfully markets its products in blue Croatia (63.7\%) (Figure 8). 


\section{JOURNAL OF TOURISM AND SERVICES}

Issue 20, volume 11, ISSN 1804-5650 (Online)

www.jots.cz

Figure 8. Green Croatia successfully sells its products to the market in blue Croatia

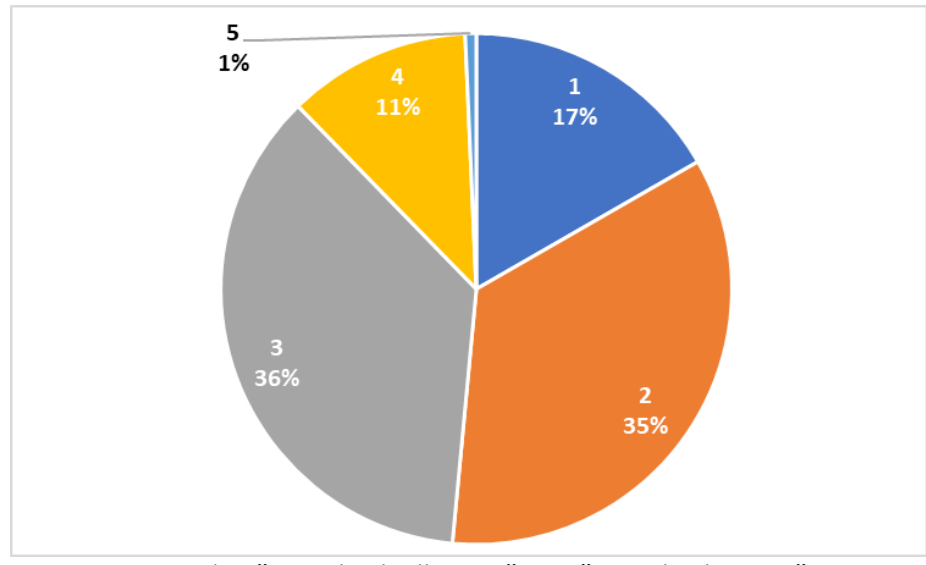

Legend: 1 "completely disagree"... 5 "completely agree"

Source: Authors

The objective of efficient tourism promotion is to attract, engage and retain visitors by offering them quality content to elicit or reinforce behaviour, which in turn leads to long-term customer loyalty, i.e., repeat usage. The largest number of respondents noted that they considered consistency in quality most important for successful product placement. By maintaining a consistently high level of quality, the products will not oscillate, and consumers will not have a different perception when tasting the product. Experts also gave a high average rating for the origin of products and groceries marketed as well as the skills to produce the product according to the domestic recipe. We can conclude that, according to a sample of experts, the factors in product preparation are most important. The products exported from green Croatia require a high level of expertise in the preparation itself, which can be seen in our research results. As can be seen in the results, online marketing and promotion also play an important role. Respondents consider offline marketing activities as the least important. The results are shown in Table 3 below.

Table 3. Factors for successful placement of gastronomic products

\begin{tabular}{|l|l|l|l|l|}
\hline $\mathbf{N = 1 3 4}$ & $\mathbf{M}$ & SD & Me & Mo \\
\hline $\begin{array}{l}\text { The cost of the product (assuming it is a domestic } \\
\text { product) }\end{array}$ & 3.63 & 0.90 & 4 & 4 \\
\hline Standard Quality - Product Consistency & 4.46 & 0.74 & 5 & 5 \\
\hline Standardisation Mark (ISO, Halal, Kosher, etc.) & 3.73 & 1.06 & 4 & 4 \\
\hline $\begin{array}{l}\text { Human resources (skills in product production by } \\
\text { following a homemade recipe) }\end{array}$ & 4.13 & 0.82 & 4 & 4 \\
\hline Packaging & 4.06 & 0.81 & 4 & 4 \\
\hline $\begin{array}{l}\text { Online marketing activities (website, search engine } \\
\text { optimisation (SEO), email marketing, PPC (Pay-Per- } \\
\text { Click), online advertising, social media) }\end{array}$ & 3.87 & 1.07 & 4 & 4 \\
\hline $\begin{array}{l}\text { Offline marketing activities (various types of prints, } \\
\text { catalogs, brochures, newspaper ads) }\end{array}$ & 3.44 & 1.10 & 3 & 3 \\
\hline $\begin{array}{l}\text { The pairing of gastronomic products of green } \\
\text { Croatia and blue Croatia }\end{array}$ & 3.71 & 1.16 & 4 & 4 \\
\hline
\end{tabular}




\section{JOURNAL OF TOURISM AND SERVICES}

Issue 20, volume 11, ISSN 1804-5650 (Online)

www.jots.cz

\begin{tabular}{|l|l|l|l|l|}
\hline $\begin{array}{l}\text { Information on the origin of products, raw } \\
\text { materials, and foodstuffs }\end{array}$ & 4.20 & 0.94 & 4 & 5 \\
\hline $\begin{array}{l}\text { Recipes (education) on how to prepare and } \\
\text { consume products }\end{array}$ & 3.75 & 0.98 & 4 & 4 \\
\hline
\end{tabular}

Sources: Authors

To further investigate these factors, the statistical significance of individual factors was compared to the gender of respondents. The outcome of testing for dependence has been tested with factors: age, education level, working status, monthly income and gender. Authors used Pearson correlation as they observe the relationships between the constructs. The results indicated that there exists statistical significance between gender and information on the origin of products, raw materials and foodstuffs $(\mathrm{P}=.001)$ and recipes (education) on the preparation and consumption of the product $(\mathrm{P}=.000)$. These variables are important for females when consuming and buying products, they research the origin of the product, as well as the methods (recipes) of preparation. Also, there is statistical significance for monthly income and readiness to buy domestic rather than foreign / imported products (Table 4). We can conclude that the economic situation and the budget of the household (i.e. respondents) significantly affect the purchase of domestic products that are slightly more expensive due to the method of production, but are also better because consumers know the origin of food and are willing to pay for quality. Also, research has shown that there is statistical significance between factors for the successful placement of gastronomic products and age (Table 5). We can conclude that the older generation is more willing to buy products from the area of Eastern Croatia (Green Croatia), guided by the idea that they will help the economy and how they follow certain elements when buying products.

Table 4. Variables for the successful placement of gastronomic products by monthly income

\begin{tabular}{|l|l|l|}
\hline & $\mathbf{P}$ & $\mathbf{R}$ \\
\hline $\begin{array}{l}\text { Whenever I can, I always prefer to buy domestic rather than foreign } \\
/ \text { imported products }\end{array}$ &, 005 &, $242^{* *}$ \\
\hline $\begin{array}{l}\text { I prefer products of Croatian origin than foreign / imported } \\
\text { products }\end{array}$ &, 020 &, $200^{*}$ \\
\hline Recipes (education) on how to prepare and consume products &, 042 &, $176^{*}$ \\
\hline
\end{tabular}

Significant codes: $\mathrm{p}$ - statistical significance at the 0.01 significance level; $\mathrm{r}-$ the Pearson correlation coefficient

Source: Authors

Table 5. Variables for the successful placement of gastronomic products by age

\begin{tabular}{|l|l|l|}
\hline & $\mathrm{P}$ & $\mathrm{r}$ \\
\hline $\begin{array}{l}\text { Whenever I can, I always prefer to buy domestic rather than } \\
\text { foreign / imported products }\end{array}$ &, 010 &, $21^{*}$ \\
\hline $\begin{array}{l}\text { I prefer products of Croatian origin than foreign / imported } \\
\text { products }\end{array}$ &, 012 &, $217^{*}$ \\
\hline $\begin{array}{l}\text { I'm trying to buy domestic products to help the Croatian } \\
\text { economy. }\end{array}$ &, 001 &, $283^{* *}$ \\
\hline Standardization label (ISO, Halal, Kosher, etc.) &, 004 &, $246^{* *}$ \\
\hline $\begin{array}{l}\text { Human resources (skills in the production of products through } \\
\text { domestic recipes) }\end{array}$ &, 008 &, $230^{* *}$ \\
\hline
\end{tabular}




\section{JOURNAL OF TOURISM AND SERVICES}

Issue 20, volume 11, ISSN 1804-5650 (Online)

www.jots.cz

\begin{tabular}{|l|l|l|}
\hline $\begin{array}{l}\text { Offline marketing activities (various types of publications, } \\
\text { catalogs, brochures, newspaper ads) }\end{array}$ &, 026 &, $192^{*}$ \\
\hline $\begin{array}{l}\text { Information on the origin of products, raw materials and } \\
\text { foodstuffs }\end{array}$ &, 047 &, $172^{*}$ \\
\hline Recipes (education) on how to prepare and consume products &, 015 & $, 20)^{*}$ \\
\hline
\end{tabular}

Significant codes: $\mathrm{p}$ - statistical significance at the 0.01 significance level; $\mathrm{r}-$ the Pearson correlation coefficient

Source: Authors

According to this research and based on statistically significant variables, we can conclude that the female population is more important in certain aspects than the male population. An important prerequisite for buying domestic products is monthly income that provide individuals with opportunities to be able to afford domestic products. Also, we can conclude that tourist experts try to consume domestic rather than foreign products and that standardization mark is important by different age groups. Based on the aforementioned, a gender-oriented marketing strategy can be created, where the emphasis will be placed on the origin and product recipe for successful placement and identification of green Croatia tourist products. It is important to create marketing preconditions so that tourism experts can voluntarily share information on the quality of domestic products and thus become evangelicals towards tourists and other tourism businesses in the rest of Croatia (i.e. Blue Croatia). It is necessary for food producers to notice which variables are important to consumers when placing products on the market and through targeted marketing strategies to focus on those elements that will enable a better appearance on the market.

\subsection{Blue and Green Croatia Connection - Good Practice Example}

In the last several years, we have heard many times about the need to start processes and connect blue and green Croatia by means of tourism. Although this has been said multiple times by economy experts and politicians, it is hard to find examples in practice. One of the rare examples of connecting blue and green Croatia in tourism is Jadranka Group and their Lošinj Hotels \& Villas (LH\&V) in Mali Lošinj.

$\mathrm{LH} \& \mathrm{~V}$ has always paid special attention to the quality of the gastronomic offer, so that the hotel restaurants have always been above expected standards, and the guiding principle was to offer their guests diverse, indigenous, homemade and ecological food. They started to cooperate with family farms (OPGs) to gather top quality homemade products and implement them into the LH\&V's offer, thus enabling their guests to taste the best that Croatia can offer. For them, this form of cooperation is important because, apart from offering their guests high-quality and homemade food, they also help the local economy Currently, LH\&V is cooperating with more than 60 Croatian OPGs from the islands of Cres and Lošinj, Istria and Kvarner, Međimurje, Slavonia and Baranja. Due to a recognizable connection between green and blue Croatia within its overall offer, LH\&V is the largest purchaser of OPG products (LH\&V hotels, 2018).

During their stay in LH\&V hotels and villas, Croatian and foreign guests can become familiar with indigenous Croatian products throughout the year, depending on the season and the current offer. There are olive oil, various sheep and goat milk cheeses, lamb and boškarin meat, Drniš prosciutto and cured meat products of Slavonia and Baranja. The basis of gastronomic offerings is primarily fresh and seasonal foods, with emphasis on their local origin and availability depending on the season. New products are tested every day and new menus are designed to raise the existing service to a higher level. The guests respond very well to homemade food and seasonal foods and often ask for these because they have become a symbol of the LH\&V offer (Rihelj, 2017). 


\section{JOURNAL OF TOURISM AND SERVICES}

Issue 20, volume 11, ISSN 1804-5650 (Online)

www.jots.cz

These projects are not easy and carry some challenges, such as logistics costs or finding the right way to transport. Cooperation in logistics is easier with local OPGs since most of them deliver their products daily following the needs of LH\&V hotels, restaurants, and shops. On the other hand, cooperation with OPGs outside the islands of Cres and Lošinj is somewhat more complicated. For logistics purposes, $\mathrm{LH} \& \mathrm{~V}$ hotels strive for a lower order frequency and larger volumes of orders to reduce transportation costs, while each possible surplus of food is redirected to existing Jadranka Group stores. According to Rihelj (2017), the biggest challenges in cooperation with OPGs from other parts of Croatia are transport and warehousing of goods in a temperature regime. $L H \& V$ representatives stated that this situation could be easily improved by government subsidies, which would then enable OPGs to market their products in the whole country.

$\mathrm{LH} \& \mathrm{~V}$ hotels buy eco-labelled products. Since there is a relatively small quantity of such products, since they are of better quality than imported goods, and since they have a much shorter shelf life, their price is much higher. But LH\&V hotels are not burdened by this cost as the quality of such products cannot be compared to industrial products.

A company is in constant contact with their current partners with whom they have signed multiyear contracts. At the end of every season, they produce a summary and plan investments for the next year. Additionally, at the beginning of a calendar year, $\mathrm{LH} \& \mathrm{~V}$ representatives are engaged in discussions with all interested OPGs in Croatia. This allows LH\&V to select products and agree on approximate quantities that will be distributed to stores, hotels, and restaurants within the group. LH\&V organizes fairs and meetings to procure certain products or look for OPGs (Rihelj, 2017). The result of this practice is that OPGs contact LH\&V directly to offer their products. Although LH\&V practice is precedent among other hotel chains, they are looking forward to increasing business cooperation and further promotion of OPGs they are working with.

\section{Conclusion}

Stronger connections between continental (green) and coastal (blue) Croatia is one of the oldest economic concepts. It has changed throughout history, but the development of tourism as an economic branch has opened new possibilities. The economic value of this concept lies in great agricultural production in continental Croatia, which can be sold in its coastal counterpart through tourism. Though agricultural production is only one of economic branches, it is important for continental Croatia, and it can influence total production.

Connections between blue and green Croatia could develop in at least two ways. A product produced in the green part could be sold as a final product in its blue counterpart, or the blue counterpart could suggest trips to the green part as a benefit or some sort of new experience to its tourists. However, all interested parties have expressed their interest in establishing such connections, but to achieve better results, local, regional and national governments are expected to become more actively involved.

Based on this research, we can conclude that there are efforts to connect green and blue Croatia, but there are rare cases of successful placement of products in different markets. Research that included a sample of experts leads to the conclusion that green Croatia has branded products to enter the market of blue Croatia, but these products have not been successfully marketed. To place products on the market, there is a need for consistency of production, information on product extraction and human resources so that the product is traditionally produced. We must not ignore marketing activities that play an important role. The results of the survey tried to provide insight into the relationship between consumer ethnocentrism and demographic variables, as well as the relationship between consumer ethnocentrism and consumer behaviour. Research has shown statistical significance as it is essential to provide product information and raw materials it is made from, as well as recipes for the preparation and pairing of 


\section{JOURNAL OF TOURISM AND SERVICES}

Issue 20, volume 11, ISSN 1804-5650 (Online)

www.jots.cz

products and Variables for the successful placement of gastronomic products by age and monthly income, which can be used to create an effective strategy.

Research results fill the existing gap about tourism competitiveness and gastronomy in Croatia but at the same time, the main research limitation is that there are no available data and no previous research about this topic in the Republic of Croatia. The limitation in research is that sample is not representative of the whole country because of geographic distribution. Because the sample does not belong in the same proportion to the Blue and Green Croatia, it is a recommendation that in future research, properly distribute samples. To further promote the process of connecting blue and green Croatia as a tool to increase competitiveness, as recommendations for further research we propose to examine the potential impact of creating and implementing a program at the national level and to conduct longitudinal research on the economic impact of the LH\&V program that is aimed at connecting bluey and green Croatia on all included parties.

\section{References}

1. Agencija za investicije i konkuretntnost. (2018). Sektor prehrambene industrije. Retrieved August 20, 2019 from http://www.aik-invest.hr/sektori/prehrambena-industrija/.

2. Alderighi, M., Bianchi, C., \& Lorenzini, E. (2016). The impact of typical products on the decision to (re)visit a tourist destination: market-expanding or business-stealing? Tourism Management, 57, 323-333.

3. Alebaki, M., \& Iakovidou, O. (2011). Market segmentation in wine tourism: A comparison of approaches. Tourismos, 6(1), 123-140.

4. Angelkova, T., Koteski, C., Jakovlev, Z., \& Mitrevska, E. (2012). Sustainability and competitiveness of tourism. Procedia - Social and Behavioral Sciences, 44, 221-227. doi: 10.1016/j.sbspro.2012.05.023

5. Baltescu, C. A. (2016). Culinary experiences as a key tourism attraction. Case Study: Braşov County. Bulletin of the Transilvania University of Braşov - Series V, 9(2), 107-112.

6. Berbel-Pineda, J. M., Palacios-Florencio, B., Ramírez-Hurtado, J. M., \& Santos-Roldán, L. (2019). Gastronomic experience as a factor of motivation in the tourist movements, International Journal of Gastronomy and Food Science. doi:10.1016/j.ijgfs.2019.100171.

7. Buturac, G., \& Vizek, M. (2015). Izvoz prehrambene industrije i učinci na gospodarstvo: slučaj Hrvatske. Ekonomski pregled, 66(3), 203-230.

8. Chi, G.-Q. C., Chua, B. L., Othman, M., \& Ab Karim, S. (2013). Investigating the Structural Relationships Between Food Image, Food Satisfaction, Culinary Quality, and Behavioral Intentions: The Case of Malaysia. International Journal of Hospitality \& Tourism Administration, 14(2), 99-120. doi:10.1080/15256480.2013.782215

9. Crouch, G. I. (2010). Destination Competitiveness: An Analysis of Determinant Attributes. Journal of Travel Research, 20 (10), 1-19.

10. Daries R. N., Cristóbal Fransi, E., Ferrer-Rosell, B., \& Mariné Roig, E. (2018). Behaviour of culinary tourists: A segmentation study of diners at top-level restaurants. Intangible Capital, 14(2), 332-355.

11. Deveci, B., Turkmen, S., \& Avcikurt, C. (2013). Kırsal Turizm Ile Gastronomi Turizmi Ilişkisi: Bigadiç Orneği. International Journal of Social and Economic Sciences, 3(2), 29-34.

12. Dimanche, F. (2005). Conceptual Framework for City Tourism Competitiveness. WTO Forum. New Paradigms for City Tourism Management. Istanbul, Turkey, 1-3 June.

13. Dkhili, H. (2018). Environmental performance and institutions quality: evidence from developed and developing countries. Marketing and Management of Innovations, (3), 333-344. doi:10.21272/mmi.2018.3-30 


\section{JOURNAL OF TOURISM AND SERVICES}

Issue 20, volume 11, ISSN 1804-5650 (Online)

www.jots.cz

14. Drpić, K., \& Vukman, M. (2014). Gastronomija kao važan dio turističke ponude u hrvatskoj. Praktični menadžment, 5 (1), 62-67.

15. Državni zavod za statistiku. (2018). Foreign trade in goods of the Republic of Croatia - Provisional Data January - April 2018 and January - May 2018. Retrieved August 25, 2019 from https://www.dzs.hr/.

16. du Rand, G. E., \& Heath, E. (2006). Towards a framework for food tourism as an element of destination marketing. Current issues in tourism, 9(3), 206-234. doi:10.2164/cit/226.0.

17. Dwyer, L. \& Kim, C. (2003). Destination Competitiveness: Determinants and Indicators. Current Issues in Tourism, 6 (5), 369-414. doi: 10.1080/13683500308667962

18. Ellis, A., Park, E., Kim, S., \& Yeoman, I. (2018). What is food tourism? Tourism Management, 68, 250-263. doi:10.1016/J.TOURMAN.2018.03.025

19. Enright, M., \& Newton, J. (2005). Determinants of tourism destination competitiveness in Asia Pacific: Comprehensiveness and universality. Journal of Travel Research, 43 (4), 339-350.

20. Gozgor, G., \& Demir, E. (2018). The Effects of Economic Policy Uncertainty on Outbound Travel Expenditures. Journal of Competitiveness, 10(3), 5-15. doi: 10.7441/joc.2018.03.01

21. Haseeb, M., Hussai, H. I., Kot, S., Androniceanu, A., Jermsittiparsert, K. (2019). Role of social and technological challenges in achieving a sustainable competitive advantage and sustainable business performance. Sustainability, 11(14), 3811. doi: 10.3390/su11143811

22. Henderson, J. C. (2004). Food as a Tourism Resource: A View from Singapore. Tourism Recreation Research, 29(3), 69-74. doi:10.1080/02508281.2004.11081459

23. Hjalager, A. M. (2004). What do tourists eat and why? Towards a sociology of gastronomy and tourism. Tourism, 52(2), 195-201.

24. Horng, J.-S., \& (Simon) Tsai, C.-T. (2010). Government websites for promoting East Asian culinary tourism: A cross-national analysis. Tourism Management, 31(1), 74-85. doi:10.1016/j.tourman.2009.01.009

25. Ignatov, E., \& Smith, S. (2006). Segmenting Canadian culinary tourists. Current Issues in Tourism, 9(3), 235-255. doi:10.2167/cit/229.0.

26. Kalenjuk, B., Cvetković, B., Blanuša, J. D., \& Lukić, T. (2018). Authentic food of Hungarians in Vojvodina (North Serbia) and its significance for the development of food tourism. World Scientific News, 106, 151-162.

27. Kendiukhov, I., \& Tvaronavičiené, M. (2017). Managing innovations in sustainable economic growth. Marketing and Management of Innovations, (3), 33-42. doi:10.21272/ mmi.2017.3-03

28. Kim, Y. G., Eves, A., \& Scarles, C. (2009). Building a model of local food consumption on trips and holidays: A grounded theory approach. International Journal of Hospitality Management, 28(3), 423-431. doi:10.1016/j.ijhm.2008.11.005.

29. Kivela, J., \& Crotts, J. C. (2005). Gastronomy Tourism. Journal of Culinary Science \& Technology, 4(23), 39-55. doi:10.1300/J385v04n02_03

30. Kozicka, K., Kot, S., Gede Riana, I. (2019). The efficiency of cooperation between the participants in the supply chain in the tourism-related branch of industry in relation to client satisfaction. Sustainability, 11(17), 4716. doi: 10.3390/su11174716

31. Kumar, G. M. K. (2019). Gastronomic Tourism - A Way of Supplementing Tourism in the Andaman \& Nicobar Islands. International Journal of Gastronomy and Food Science, 16. doi:10.1016/j.ijgfs.2019.100139

32. López-Guzmán, T., \& Sánchez-Cañizares, S. (2012). Gastronomy, tourism and destination differentiation: a case study in Spain. Review of Economics \& Finance, 2, 63-73.

33. López-Guzmán, T., Tores-Naranjo, M., Perez-Gavez, J. C., \& Carvache, F. W. (2018). Gastronomic perception and motivation of a touristic destination: The city of Quito, Ecuador. GeoJournal of Tourism and Geosites, 21(1), 61-73. 


\section{JOURNAL OF TOURISM AND SERVICES}

Issue 20, volume 11, ISSN 1804-5650 (Online) www.jots.cz

34. Lošinjka hoteli i vile. (2018). Lošinj Hotels and Vilas. Retrieved August 22, 2019 from https://www.losinj-hotels.com/.

35. Luštický M. \& Kincl, T. (2012). Tourism Destination Benchmarking: Evaluation and Selection of the Benchmarking Partners. Journal of Competitiveness, 4 (1), 99-116. doi: 10.7441/joc.2012.01.08

36. Mangion M.-L., Durbarry R., \& Sinclair M. T. (2005). Tourism competitiveness: price and quality Tourism competitiveness: price and quality.Tourism Economics, 11(1), 45-68.

37. Mészáros, M., Divékyová, K. (2019). Immediate termination of employment relationship by the employer. Central European Journal of Labour Law and Personnel Management, 2 (2), 33-43. doi: 10.33382/cejllpm.2019.03.03

38. National Bureau of Statistics. (2018). Tourism - review from 1954. Retrieved August 25, 2019 from https://www.dzs.hr/Hrv_Eng/Pokazatelji/Turizam-pregled1954.xlsx.

39. Navickas, V. \& Malakauskaite, A. (2009). The Possibilities for the Identification and Evaluation of Tourism Sector Competitiveness Factors. Engineering economics, 1 (61), 37-44.

40. Okumus, B., Okumus, F., \& McKercher, B. (2007). Incorporating local and international cuisines in the marketing of tourism destinations: The cases of Hong Kong and Turkey. Tourism Management, 28, 253-261. doi:10.1016/j.tourman.2005.12.020.

41. Palić, P. (2018). Sektorske analize - Hrana i piće. Retrieved August 25, 2019 from https://www.eizg.hr/userdocsimages/publikacije/serijske-publikacije/sektorskeanalize/SA_hrana-2018.pdf.

42. Peleckis, K., Peleckiene, V., Peleckis, K. (2018). The search for balance and equilibrium of negotiating powers under distorted market competition. Ekonomicko-manazerske spektrum, 12(2), 67-82.

43. Pérez Gálvez, J. C., López-Guzmán, T., Cordova Buiza, F., \& Medina-Viruel, M. J. (2018). Gastronomy as an element of attraction in a tourist destination: the case of Lima, Peru, Journal of Ethnic Foods, 4 (4), 254-261. doi:10.1016/j.jef.2017.11.002.

44. Pjerotic, L. (2017). Stakeholder cooperation in implementation of the sustainable development concept: Montenegrin tourist destinations. Journal of International Studies, 10(2), 148-157. doi:10.14254/2071-8330.2017/10-2/11

45. Pranić, LJ. (2012). Osobitost gastronomske ponude Jadranske Hrvatske. In Crnjak-Karanović, B., Derado, D., Fredotović, M., \& Petrić, L. (eds.) Identitet jadranskog prostora Hrvatske: Retrospekt i prospect (253-266), Split: Ekonomski fakultet

46. Rihelj, G. (2017). Spoj Plave i Zelene Hrvatske - zvuči poznato? Retrieved August 20, 2019 from http:/ / hrturizam.hr/spoj-plave-zelene-hrvatske-je-moguc-jadranka-grupa-suraduje-s-preko-60opg-iz-cijele-hrvatske/.

47. Ritchie, J. R. B., \& Crouch, G. I. (2003). The competitive destination: A sustainable tourism perspective. Wallingford: CABI Publishing

48. Seal, P. P. \& Piramanayagam, C. (2018). Branding geographical indication (GI) of food and its implications on gastronomic tourism: An Indian perspective. In Proceedings of 8th Advances in hospitality and tourism marketing and management (AHTMM) Conference, Bangkok, Thailand, pp. 132-136.

49. Sharma, K. K. (2004). Tourism and Regional Development. New Delhi: Sarup \& Sons.

50. Shimp, A. T. and Sharma, S. (1987). Consumer Ethnocentrism: Construction and Validation of the CETSCALE, Journal of Marketing Reseach, 24 (3).

51. Sormaz, U., Akmese, H., Gunes, E. \& Aras, S. (2016). Gastronomy in tourism. Procedia Economics and Finance, 39, 725-730.

52. Sudarić, T., Zmaić, K., \& Čepo, V. (2020). Razvoj eno-gastronomske turističke destinacije. In Mioč, B. \& Sirić, I. (eds.) Proceedings of $55^{\text {th }}$ Croatian and $15^{\text {th }}$ International Symposium on Agriculture (114-118), Zagreb: Agronomski fakultet.

53. Vanhove, N. (2002). Tourism policy: Between competitiveness and sustainability - The case of Bruges. The Tourist Review, 57(3), 34-40. 
54. Veljković, S. (2009). Uticaj etnocentrizma na potrošače u Srbiji. Casopis za marketing teoriju i praksu - QMJ - Quarterly Marketing Journal, 16(1), 97-106

55. Vlada Republike Hrvatske (2013). "Strategija razvoja turizma Republike Hrvatske do 2020. godine." Ministarstvo turizma, Zagreb, Croatia.

56. Yozukmaz, N., Bekar, A., \& Kilic, B. (2017). A conceptual review of "foodies" in tourism. Journal of Tourism and Gastronomy Studies, 5(4), 170-179. doi:10.21325/jotags.2017.144.

57. Zahari, M. S. M., Jalis, M. H., Zulfifly, M. I., Rodzi, S. M. \& Othman, Z. (2009). Gastronomy: An Opportunity for Malaysian Culinary Educators. International Education Studies, 2(2), 66-71. doi:10.5539/ies.v2n2p66.

\section{Brief description of Author/Authors:}

\section{Ivan Kelić, PhD}

Assistant Professor at J. J. Strossmayer University of Osijek, Faculty of Economics in Osijek. His research interests are in online marketing, marketing management and consumer behaviour.

\section{Aleksandar Erceg, PhD}

Associate Professor at J. J. Strossmayer University of Osijek, Faculty of Economics in Osijek. His research interests are in entrepreneurship, corporate entrepreneurship, franchising and operations management.

\section{Ivana Čandrlić-Dankoš, PhD}

Assistant Head of the Department of Investment, Development Projects and European Union Funds in Osijek-Baranja County. Her research interests are in European funding and strategic planning. 